\title{
O Tamanho dos Ninhos Expansivos Juncionais pode Predizer o Comportamento dos Melanomas in situ
}

\author{
Luciana Pantaleão', Licínio Esmeraldo Silva², Mayra Carrijo Rochael ${ }^{3}$ \\ 'Assistant Professor of Anatomic Pathology, Department of Pathology, Fluminense Federal University, Niterói, RJ - Brazil; \\ Dermatopathologist certified by the International Society of Dermatopathology \\ ${ }^{2}$ Adjunct professor of Biostatistics; Department of Statistic, Fluminense Federal University, Brazil \\ ${ }^{3}$ Associate professor of Anatomic Pathology; Department of Pathology, Fluminense Federal University \\ Dermatopathologist certified by the International Society of Dermatopathology, Brazil
}

\section{Size of the Junctional Nests can Predict in situ Melanoma Behavior}

KEY-WORDS - Carcinoma in situ; Neoplasm Metastasis; Melanoma; Skin Neoplasms; Neoplasm Staging; Prognosis; Recurrence.

In recent years, the diagnosis of in situ melanoma (MIS), considered of excellent prognosis, has increased. ' Some authors have reported isolated cases of MIS presenting recurrence, metastasis and death. , $^{3}$ However, so far, no study has identified the causes of this unexpected behavior.

Cook et al (2002), studying thin metastasizing melanomas, suggested that those lesions with follicular invasion and expansive junctional nodules should be considered vertical growth phase melanomas. They also described a case without these or others features of high-risk lesion, that still metastasized. ${ }^{4}$

Kutzner et al (2012) reported a new variant of superficial spreading melanoma based on histological and genetic evidence consisting exclusively or predominantly by large, irregular, atypical melanocytic junctional nests. The authors emphasized that the 11 cases were initially diagnosed as MIS and, after several serial sections, atypical melanocytes infiltrating the dermis were identified in five cases. ${ }^{5}$

We identified 445 cases of primary MIS in two hospitals of Rio de Janeiro state, between 1998 and 2010, reviewing the slides to classify them as "large nests in situ melanomas" and other histopathological aspects. All cases were treated surgically with, at least, $5 \mathrm{~mm}$ free margins. The results were correlated to the outcome. For those "large nests in situ melanomas", we used Aperio ImageScope system to measure the largest nest diameter.
Eighteen cases (4.04\%) presented almost exclusively by large irregular nests, matching the description of the variant reported by Kutzner et al. ${ }^{5}$ Among these, we identified a patient who developed recurrence 61 months after the diagnosis. Five patients between the other 427 cases presented recurrence and three developed regional metastasis.

The correlation between this variant and the occurrence of relapse or metastasis showed no statistical significance by Fisher exact test $(a=0.05, p=0.313)$. However, considering the size of the junctional nests, the largest nests were found in the only case of recurrence among the 18 cases with large nests, except one of the group with no recurrence (Fig. 1). This difference was relevant on Student $t$ test $(t=-7.270 ;$ f.g. $=16$; $p<0.0001)$. Although we had a case in the group without recurrence with nests of a similar diameter, the presence of other 16 cases with much smaller nests in the same group allowed statistical support for this finding.

Among those eighteen cases, twelve had also anexotropism and three showed late regression, but none of these variants (anexotropism and regression) had statistically significant correlation with recurrence and/or metastasis.

Our findings agree with the concept of expansive junctional nodules as high-risk feature previously reported by Cook et al in $2003^{4}$ and Kutzner et al in 2012. ${ }^{5}$
Correspondência: Luciana Pantaleão

Rua Raimundo Correa, 39/701 - Copacabana, Rio de Janeiro, RJ

ZIPcode: 22040-041, Brazil

Tel.: 55 (21) 21350488

E-mail: lupantaleao@yahoo.com.br
Recebido/Received

1 Setembro/September 2016

Aceite/Accepted

8 Novembro/November 2016 


\section{Carta ao Editor}

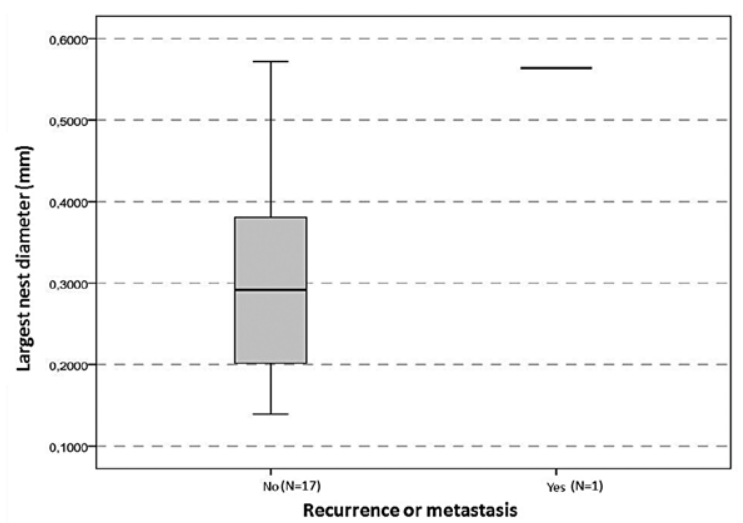

Figura 1 - Largest nest diameter of 18 MIS showing almost exclusive large nests and development of recurrence or metastasis $(p<0.0001)$.

We have found one case of MIS with local recurrence, in which the main histopathological feature was the predominance of expansive and large junctional nests. The papillary dermis showed a light fibrosis but, since there was no decrease of the number of melanoma cells, these alterations have not filled the criteria for regression. In search for melanoma cells in the dermis serial sections were performed but those cells were not found, confirming the initial diagnosis.

Although based in only one case, we believe that the size of the nests could explain this unexpected behavior, since its largest nest $(0.57 \mathrm{~mm}-$ Fig. 2$)$ was larger than the mean largest nest size $(0.3 \mathrm{~mm})$ of the group with no recurrence.

To our knowledge, this is the first time that expansive nests have been measured and compared to outcome. Since there are few studies on the subject in the literature, this finding contributes to alert pathologists and clinicians about the importance of recognizing this variant.

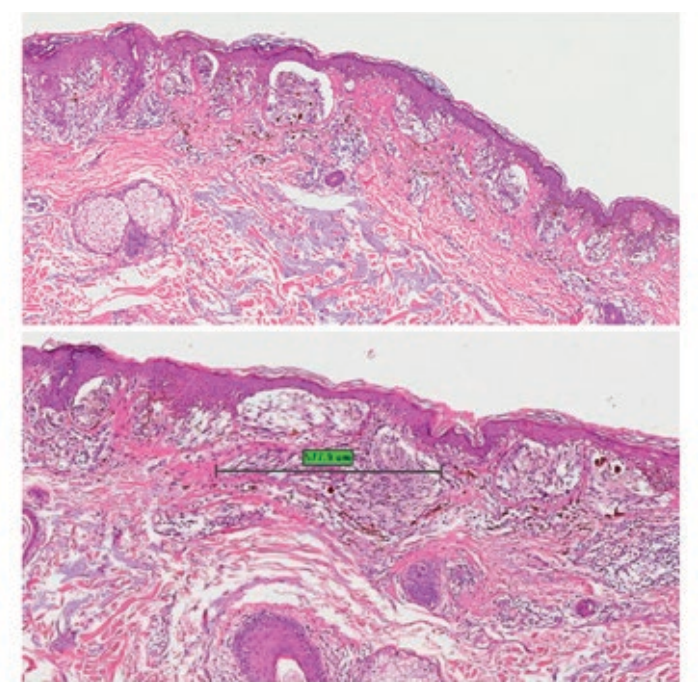

Figura 2 - Primary MIS with posterior recurrence: A) constituted almost exclusively by large nests; B) the largest nest width measuring $0.57 \mathrm{~mm}$ (B) $(H \& E)$
Even though these rare cases of MIS with poor prognosis remains unexplained, we believe that the presence and size of expansive junctional nests must not be overlooked when the diagnosis of MIS is suspected. One limitation of our study is the small number of MIS with bad outcome and also with large nests. Further studies with larger number of cases may contribute to confirm this found and possibly establish a cut off size for a large nest.

Conflitos de interesse: Os autores declaram não possuir conflitos de interesse.

Suporte financeiro: $O$ presente trabalho não foi suportado por nenhum subsídio ou bolsa.

Confidencialidade dos dados: Os autores declaram ter seguido os protocolos do seu centro de trabalho acerca da publicação dos dados de doentes.

Protecção de pessoas e animais: Os autores declaram que os procedimentos seguidos estavam de acordo com os regulamentos estabelecidos pelos responsáveis da Comissão de Investigação Clínica e Ética e de acordo com a Declaração de Helsínquia da Associação Médica Mundial

Conflicts of interest: The authors have no conflicts of interest to declare.

Financing Support: This work has not received any contribution, grant or scholarship.

Confidentiality of data: The authors declare that they have followed the protocols of their work center on the publication of data from patients.

Protection of human and animal subjects: The authors declare that the procedures followed were in accordance with the regulations of the relevant clinical research ethics committee and with those of the Code of Ethics of the World Medical Association (Declaration of Helsinki).

\section{REFERENCES}

1. Gimotty PA, Guerry D. Prognostication in thin cutaneous melanoma. Arch Pathol Lab Med. 2010; 134:1758-63.

2. Guitart J, Lowe L, Piepkorn M, Prieto VG, Rabkin MS, Ronan SG, et al. Histological characteristics of metastasizing thin melanomas - a case-control study of 43 cases. Arch Dermatol. 2002; 138:603-7.

3. Megahed M, Schön M, Selimovic D, Schön MP. Reliabiliy of diagnosis of melanoma in situ. Lancet. 2002; 359:1921-2.

4. Cook MG, Spatz A, Bröcker EB, Ruiter DJ. Identification of histological features associated with metastatic potential in thin $(<1.0 \mathrm{~mm})$ cutaneous melanoma with metastases. A study on behalf of the EORTC Melanoma Group. J Pathol. 2002; 197:188-93.

5. Kutzner H, Metzler G, Argenyi Z, Requena L, Palmedo $G$, Mentzel T, et al. Histological and genetic evidence for a variant of superficial spreading melanoma composed predominantly of large nests. Mod Pathol. 2012; 25: 838-45. 